\title{
Do medical interns feel prepared to work in the COVID-19 pandemic?
}

\author{
(iD Maria Rosilene Cândido Moreira ${ }^{1}$ \\ (iD) Raul de Freitas Aquino' \\ (iD Larissa Lima Barros ${ }^{1}$ \\ (D) Natália Campos Parente ${ }^{\mathbf{1 , 2}}$ \\ (D) Maria de Fátima Antero Sousa Machado ${ }^{\mathbf{1 , 2}}$ \\ (iD) Anderson Milfont Feitosa de Oliveira,2 \\ (iD) Estelita Lima Cândido'
}

1. Universidade Federal do Cariri, Barbalha, CE, Brasil. 2. Fundação Oswaldo Cruz - Fiocruz/Ceará, Eusébio, CE, Brasil.

http://dx.doi.org/10.1590/1806-9282.66.7.973

\section{SUMMARY}

OBJECTIVE: To learn about the perceptions of medical internship students about the early conclusion of the course and their preparation to act in the fight against COVID-19.

METHODS: An online questionnaire was applied with questions about the socioeconomic profile and the object of investigation. The data were analyzed using the Bioestat 5.0 software.

RESULTS: 111 students participated, most of whom (61.3\%) were male, aged 20 to 25 years (80.2\%), of Catholic religion (57.5\%), and attending the 2 nd year of internship (50.5\%). A small portion (22.5\%) reported being in total social isolation. The majority (57.5\%) considered themselves unprepared to act in the fight against the pandemic, and $86.8 \%$ of the students believe that the early conclusion of the course will contribute to the fight against COVID-19 in the country.

CONCLUSION: This scenario points to the urgency of measures that provide, to recent graduates, timely technical preparation, safe work conditions, and emotional support even at the beginning of their professional career, leading them to competent, dignified and healthy work, during and after the pandemic.

KEYWORDS: Pandemics. Coronavirus. Public Health. Internship and Residency.

\section{INTRODUCTION}

The novel coronavirus pandemic that started in December 2019 in Wuhan, China, due to the potential of lethality related to the massive alveolar damage and progressive pulmonary failure caused by the Sars-COV-2 virus, has consolidated itself as a matter of global concern' ${ }^{1}$.

Initially classified as an epidemic, Covid-19 spread among the Chinese and foreigners who were in that province at the end of that year and, due to its rapid spread across several countries and continents, on 30 January 2020, it was promoted to a Public Health Emergency of International Importance ${ }^{2.3}$.

In Brasil, the first confirmed case of Covid-19 was recorded on 26 February 2020, imported from Italy, and by 23 May over 310,000 confirmed cases and 20,000 deaths had already been recorded in the 
country, triggering the need for intensification of specific strategic actions to control the spread of the disease and the number of severe hospitalizations ${ }^{4.5}$.

Among the combat possibilities announced by the Brazilian Federal Government, the Ministry of Education (MEC) took the exceptional measure, through the publication of Decree 374, on 3 April 2020, and subsequently repealed by Decree 383, on 9 April 2020, of allowing the early graduation of health students to fight the Covid-19 pandemic ${ }^{6.7}$.

Under the allegation that health professionals, particularly doctors and nurses, would be taken away from their positions due to the virus and in face of the substantial increase of patients in need of hospital care, the MEC considered that the measure would make more professionals available to work in the context of the pandemic and thus meet shortages of workers like the ones that were already taking place in states where the incidence of the disease is high ${ }^{8}$.

One Brazilian states that experienced the early graduation of medical students and other health programs was Ceará. With eight medical programs offered in the state, the press reported, on the day following the publication of Decree 383 by the MEC, the early graduation of the first 82 students of the medicine, physiotherapy, and nursing programs, who are now authorized to act in health services of the entire country ${ }^{9.10}$.

On the other hand, on 15 April 2020, the press reported that 28 health professionals in Ceará had been removed from their positions due to confirmed contamination by Covid-19, among them: eight nursing technicians/assistants, five doctors, and three nurses. Other 109 workers were suspected of having contracted the disease and were awaiting the results of serology $y^{11}$.

In this scenario, and considering that the early graduation had the purpose of expanding the labor force available to the care of hospitalized patients, we present the following question: do students consider themselves prepared for the management of infected patients and other actions to fight Covid-19? What do they think about the early graduation to act in the context of the pandemic?

Understanding the perspective of students who are enrolled in the last periods of programs on such issues can assist in the elucidation of the challenges and possible fears related to this atypical moment experienced by all, which would allow us to have targeted and safe strategies for the work of these young professionals.
Thus, the goal of this study was to investigate the perceptions of medical interns about early graduation and preparation to work in the combat against the Covid-19 pandemic.

\section{METHODS}

This is a cross-sectional study, of the opinion poll type, with no identification of its participants, based on the provisions of the Resolution 510/2016 of the National Health Council, conducted through online questionnaires on the Google Forms Platform sent to all students duly enrolled in the last two years of the medical program of a public university in the state of Ceará, totaling a pool of 166 students. Data collection began on 3 April, when the first ordinance by the MEC on the matter was issued, and ended on 22 April, when the necessary sample size was achieved, considering a confidence interval of $95 \%$ and error of $5 \%$.

The questionnaire was prepared with sociodemographic variables and the questions: Do you believe you are prepared to handle the Covid-19 in your professional practice? What your behavior regarding social isolation? Did you request early graduation? Are you familiar with the protocols and guidelines by the Ministry of Health for the management of Covid-19? Do you believe that early graduation will contribute to the fight against the pandemic?

The data were exported from the Google Forms platform in the format of an electronic spreadsheet and analyzed using Bioestat 5.0. The absolute and relative frequencies of all variables of the study were calculated, and the association between them was verified by the G test (Wiliams). Statistical significance was considered when $\mathrm{p}<0.05$.

\section{RESULTS}

The study sample consisted of 111 students, most of which (50.5\%) enrolled in the $2^{\text {nd }}$ year of internship. Regarding sex, $61.3 \%$ of the population was male and $38.7 \%$ female. The ages were mostly in the age group of 20 to 25 years $(80.2 \%)$. As to family income, we found that $55 \%$ were in the range of up to four minimum wages, $40.5 \%$ in the range of over four minimum wages, and $4.5 \%$ reported a family income of less than one minimum wage. Most declared to be Catholic (57.7\%), and 26.1\% stated they have no religion.

When asked about the practice of social isolation, only $22.5 \%$ said they were practicing the "total" type, 
i.e., are not leaving their homes or receiving visits; of those who reported being in partial isolation, $72.1 \%$ justified it by claiming they needed to leave the house to go to the pharmacy and/or supermarket, 4.5\% reported leaving a few times to visit family and/or friends, and one person claimed not to leave the house but receive the visit from someone hired to perform domestic services daily.

Regarding their preparation to act as doctors in the fight against Covid-19, 57.7\% said they did not consider themselves prepared, while $42.3 \%$ responded affirmatively. The feeling of preparation was more prevalent among: males (35.1\%), age $20-25$ years (30.7\%), with an income between one and four minimum wages (20.8\%), enrolled in the $2^{\text {nd }}$ year of internship (27.1\%), Catholics (29.7\%), with knowledge of the Covid-19 protocols (47.7\%), and who were in partial isolation (28.9\%). Except for the gender variable, all other variables significantly influenced the perception expressed by students (Table 1 ).

In a complementary manner, $95.5 \%$ of the students reported being aware of one or more ministerial protocols for the management of Covid-19, while 4.5\% reported not knowing any of the official documents; one student remarked that he did not know the existence of specific documents on the various clinical contexts involved in the pandemic. The ministerial protocols on Covid-19 known by the students are listed in Table 1.

\section{DISCUSSION}

The pandemic caused by Covid-19 has changed the daily lives of everyone significantly. It affected various aspects of people's behavior, which include work, study, family life, and even spiritual life; the topic has influenced these scenarios mediated by strategies for coping with the crisis which is still present in many places.

In Brasil, the fight against the pandemic has been made possible by the existence of a universal health care system, which features a hierarchical and regionalized network of services, and by its body of workers, which together constitute the patrimony of the country ${ }^{12}$. However, the increase in contamination among these professionals, as a result of an unhealthy working environment, exhaustive work hours, and problems regarding the supply of inputs for individual protection, results in the removal of professionals from their functions, generating the need for other professionals to join in on the frontline of health services.

Faced with this context, the Ministry of Health authorized the early graduation of health students in the last year of university so that they can help overcome shortcomings identified in places with a greater number of people affected. However, the government measure generated disagreements among professional bodies, society in general, and students themselves, bringing to the heart of the discussion aspects that involve the preparation to act and appropriate and safe work conditions for young professionals, since these students, although graduated and trained to provide care in all contexts, are not trained to handle crisis situations such as the presents one $\mathrm{e}^{13}$.

TABLE 1. ASSOCIATION BETWEEN THE PREPARATION TO ACT IN THE FIGHT AGAINST COVID-19 AND THE SOCIODEMOGRAPHIC VARIABLES OF THE INTERVIEWEES.

\begin{tabular}{|c|c|c|c|c|c|}
\hline \multirow{3}{*}{ Variables } & \multicolumn{4}{|c|}{$\begin{array}{l}\text { Preparation to act in the } \\
\text { fight against Covid-19 }\end{array}$} & \multirow{3}{*}{$p$-value } \\
\hline & \multicolumn{2}{|l|}{ Yes } & \multicolumn{2}{|c|}{ No } & \\
\hline & $f$ & $\%$ & $f$ & $\%$ & \\
\hline \multicolumn{5}{|l|}{ Gender } & 0.0974 \\
\hline Female & 14 & 12.6 & 32 & 28.9 & \\
\hline Male & 39 & 35.1 & 36 & 32.4 & \\
\hline \multicolumn{5}{|l|}{ Age range } & $0.0183^{\star}$ \\
\hline $20-25$ & 34 & 30.7 & 55 & 49.5 & \\
\hline $26-30$ & 7 & 6.3 & 8 & 7.2 & \\
\hline $31-40$ & 6 & 5.4 & 0 & 0 & \\
\hline$>40$ & 0 & 0 & 1 & 0.9 & \\
\hline \multicolumn{5}{|c|}{ Income (minimum wages) } & 0.4893 \\
\hline$<1$ wage & 3 & 2.7 & 2 & 1.8 & \\
\hline 1 to 4 wages & 23 & 20.8 & 38 & 34.2 & \\
\hline$>4$ wages & 21 & 18.9 & 24 & 21.6 & \\
\hline \multicolumn{5}{|c|}{ Internship year } & $0.0159^{*}$ \\
\hline 1st year & 17 & 15.3 & 38 & 34.2 & \\
\hline 2nd year & 30 & 27.1 & 26 & 23.4 & \\
\hline \multicolumn{5}{|l|}{ Religion } & $0.0020^{*}$ \\
\hline Catholic & 33 & 29.7 & 31 & 27.9 & \\
\hline Christian & 0 & 0 & 1 & 0.9 & \\
\hline Spiritualist & 1 & 0.9 & 6 & 5.4 & \\
\hline Evangelical & 0 & 0 & 10 & 9.0 & \\
\hline No religion & 13 & 11.8 & 16 & 14.4 & \\
\hline \multicolumn{5}{|c|}{ Is familiar with Covid-19 protocols } & $0.0233^{*}$ \\
\hline Yes & 53 & 47.7 & 63 & 56.8 & \\
\hline No & 0 & 0 & 5 & 4.5 & \\
\hline \multicolumn{5}{|c|}{ Social isolation behavior } & $0.0456^{*}$ \\
\hline Partial & 32 & 28.9 & 54 & 48.6 & \\
\hline Total & 15 & 13.5 & 10 & 9.0 & \\
\hline
\end{tabular}

* Williams G-test of 0.05 . 
In the present study, medical interns gave their opinion on early graduation and preparation to act professionally in the context of a pandemic. The findings revealed that the younger ones and those in the $1^{\text {st }}$ year of internship are more insecure. We suppose that experiences acquired with age and during the internship, in addition to prior work in the health workforce, contribute so that older individuals feel more confident to act.

Religion was another significant variable in this study. Most students who declared having some kind of religious belief feel prepared to act in the fighting against the virus. It is understood that religion can positively influence students' health practices since spirituality is a human dimension that can put health and disease experiences in a meaningful context, and when medical students understand its importance, they are able to reflect on this in relation to their professional activity and themselves, which is reflected in things such as self-care and self-protection ${ }^{14}$.

Considered by the World Health Organization as a measure of self-protection, social isolation has been adopted as a way of hindering the transmission of the virus and was an aspect investigated among students, most of whom declared risk behaviors for contagion. Although all interviewees are practicing some form of isolation, most of them informed partial isolation, a similar result found by a study conducted in Ceará in the general population ${ }^{15}$. We suppose that this behavior by the students is due to the fact that part of this group lives far from their families and are the only ones responsible for acquiring basic supplies and performing essential services.

In the context of public health, the impacts caused by a virus of fast and easy propagation are severe, resulting in abrupt changes in health services due to the increased number of hospitalizations and the collapse of the health care system. Although one of the currently most widespread guidelines is social distancing, this does not include activities that are essential to society, such as those performed by health profession$\mathrm{als}^{16}$. The presence of these workers in their work environments is necessary to ensure essential care related to various health aggravations, such as Covid-19, but it may also lead to an increasingly unhealthy work environment due to the high probability of contamination related to work in this new condition of risk.

In this sense, the preparation of the students to act in health care services in the context of a pandemic was investigated in this study. Although most declared knowing at least one of the protocols by the Ministry of Health about Covid-19, a portion of the students does not feel prepared for professional practice. It should be emphasized that these young professionals, in the absence of safe work conditions, will be exposed to contamination in similarly to other workers, since, even to those who are directly involved with patients, little has been discussed about work conditions and organization, up until now, there have been protocols with recommendations of individual measures, which are important but insufficient for the general control of the spread of the disease and exposure to the virus ${ }^{17}$.

The students demonstrated knowing the ministerial protocols that involve the management of the disease at the primary or tertiary level of care, which may be due to intrinsic motivation since curriculum classes at the institution investigated have been suspended $^{18}$. However, the protocol on the use of N95 masks or equivalent was not often mentioned by the participants, which may suggest little importance attributed to the subject or ignorance about the existence of this particular document, which emphasizes

FIGURE 1. MINISTERIAL PROTOCOLS ON COVID-19 KNOWN BY THE STUDENTS

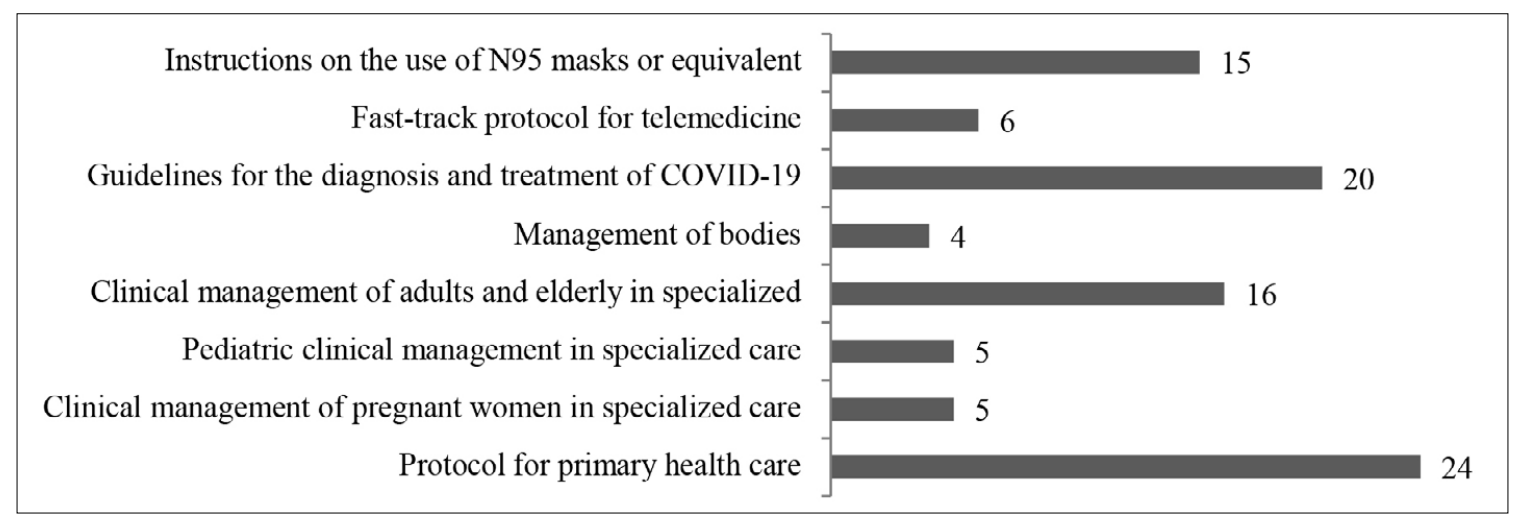


the need for raising awareness among students about the importance of personal protection, on the sufficient and safe use of PPE, and technical preparation for work, all important measures to reduce the risk of infection for health workers ${ }^{19}$.

The early graduation was also the object of this study. With the onset of the Sars-Cov-2 pandemic, several countries presented alternative tracks for the graduation of students, and the Brazilian Ministry of Education softened the requirements for regular medical internship duration, allowing also the abbreviation of programs, provided that $75 \%$ of the hourly load planned for the medical internship is completed ${ }^{20}$.

Most students in this study believe that early graduation will contribute to solving the health system crisis; however, the Federal Council of Medicine (CFM) clarifies that the early graduation of medical students is harmful to the training of future physicians, in addition to not bringing obvious benefits for the care of the population ${ }^{21}$.

It should be emphasized that the interruption of activities in medical schools, which will have an impact on the time necessary for new professionals to graduate, was another factor for consideration in the context of Brazilian universities which was taken into account in the discussions on the early graduation. In a virtual survey conducted by the Brazilian Association of Medical Education (Abem) in March and April 2020, when questioned about the interruption of activities, teachers, students, and administrators revealed a trend of slow and gradual return, without concrete prospects ${ }^{22}$.

There are still questions about the characteristics of this new and young labor force of physicians in the country after the scenario of the pandemic. With the early graduation of medical students with a course load that exceeds $75 \%$ of the total requirements, it is not possible to ensure that everyone has experienced all practical scenarios necessary for adequate training. Therefore, students who do not have sufficient practical experience in urgent and emergency or primary health care may graduate early, since the areas in question add up to $30 \%$ of the load of medical internships, which may interfere with the quality of the services provided by these professionals ${ }^{23}$.
Another issue to be considered in this context is the growing circulation of fake news about Covid-19 in social media ${ }^{24}$. Information on effective pharmacological treatments is disclosed based on inconclusive studies, leading specialized medical and scientific groups to various reflections and encouraging professional debate, which requires these newly graduated physicians to have knowledge about and discernment regarding the best practices for the clinical scenarios related to Covid- $19^{25}$.

Despite the different contexts and scenarios, in face of an unprecedented pandemic and located in a state where there is a low density of professionals, the alternative of early graduation for medical interns of the last years is a strong alternative that has been put into practice in several Brazilian medical schools.

\section{CONCLUSION}

The results of this study indicate that the debates on early medical graduation require greater depth so that the integration of recent graduates into the workforce can effectively constitute a strategy of expansion in the context of the pandemic. In addition, these findings indicate the need for improved training of these young professionals on Covid-19 and how to combat it, in addition to adequate work conditions and emotional support that lead them to a responsible, safe, and healthy practice in the context of the pandemic and after it.

\section{Author's Contribution}

Moreira MRC, Parente NC, Aquino RF, and Barros LL contributed to the concept and design of the study, data collection, analysis and interpretation of the results, preparation and critical review of the manuscript. Cândido EL, Oliveira AMF, and Machado MFAS contributed to the analysis and interpretation of the results, preparation and critical review of the manuscript. All authors approved the final version of the manuscript and declare themselves to be responsible for all aspects of the work, ensuring its accuracy and integrity. 


\section{RESUMO}

OBJETIVO: Conhecer as percepções de estudantes do internato médico sobre formatura antecipada e preparo para trabalhar no combate à pandemia da Covid-19.

MÉTODOS: Aplicou-se questionário on-line com questões sobre o perfil socioeconômico e o objeto de investigação. Os dados foram analisados pelo software Bioestat 5.0.

RESULTADOS: Participaram 117 estudantes, a maioria (61,3\%) do sexo masculino, na faixa etária de 20 a 25 anos (80,2\%), de religião católica (57,5\%) e cursando o $2^{\circ}$ ano do internato (50,5\%). Pequena parcela $(22,5 \%)$ informou estar em isolamento social total. A maioria $(57,5 \%)$ se sente despreparada para atuar no combate à pandemia, e 86,8\% consideram que a formatura antecipada contribuirá para o enfrentamento da Covid-19 no País.

CONCLUSÃO: Este panorama remete à urgência de medidas que propiciem, aos recém-graduados, preparo técnico oportuno, condições de trabalho seguras e suporte emocional já neste início de carreira profissional, conduzindo-os ao trabalho competente, digno e saudável, durante e após a pandemia.

PALAVRAS-CHAVE: Pandemias. Coronavírus. Saúde pública. Internato e residência.

\section{REFERENCES}

1. Lana RM, Coelho FC, Gomes MFC, Cruz OG, Bastos LS, Villela DAM, et al. Emergência do novo coronavírus (SARS-CoV-2) e o papel de uma vigilância nacional em saúde oportuna e efetiva. Cad Saúde Pública. 2020;36(3):e00019620.

2. Freitas $A R R$, Napimoga $M$, Donalisio MR. Análise da gravidade da pandemia de Covid-19. Epidemiol Serv Saúde. 2020;29(2):e2020119.

3. Organização Pan-Americana da Saúde. OMS declara emergência de saúde pública de importância internacional por surto de novo coronavírus. [cited 2020 May 02]. Available from: https://www.paho.org/bra/index. php?option=com_content\&view=article\&id=6100:oms-declara-emergencia-de-saude-publica-de-importancia-internacional-em-relacao-a-novo-coronavirus\&ltemid=812

4. Croda JHR, Garcia LP. Resposta imediata da Vigilância em Saúde à epidemia da COVID-19. Epidemiol Serv Saúde. 2020;29(1):e2020002.

5. BRASIL. Ministério da Saúde. Coronavirus Brasil. Painel de casos de doença pelo coronavírus 2019 (COVID-19) no Brasil pelo Ministério da Saúde. [cited 2020 May 23]. Available from: https://covid.saude.gov.br/

6. BRASIL. Ministério da Educação. Portaria 374, de 03 de abril de 2020. Dispõe sobre a antecipação da colação de grau para os alunos dos cursos de Medicina, Enfermagem, Farmácia e Fisioterapia, exclusivamente para atuação nas ações de combate à pandemia do novo coronavírus - Covid-19. Diário Oficial da República Federativa do Brasil, Poder Executivo, Brasília, DF, 06 abr. 2020. Seção I, p. 66. [cited 2020 May 23]. Available from: https:// www.normasbrasil.com.br/norma/portaria-374-2020_392453.html

7. BRASIL. Ministério da Educação. Portaria 383, de 09 de abril de 2020. Dispõe sobre a antecipação da colação de grau para os alunos dos cursos de Medicina, Enfermagem, Farmácia e Fisioterapia, como ação de combate à pandemia do novo coronavírus - Covid-19. Diário Oficial da República Federativa do Brasil, Poder Executivo, Brasília, DF, 13 abr. 2020. Seção I, p. 24. [cited 2020 May 23]. Available from: http://www.in.gov.br/en/web/ dou/-/portaria-n-383-de-9-de-abril-de-2020-252085696

8. BRASIL. Ministério da Educação. MEC autoriza formatura antecipada de estudantes de Medicina, Enfermagem, Farmácia e Fisioterapia. [cited $2020 \mathrm{Apr}$ 20]. Available from: <http://portal.mec.gov.br/index. php?option=com_content \&view=article\&id=87651>

9. BRASIL. Ministério da Educação. Cadastro Nacional de Cursos e Instituições de Educação Superior - Cadastro e-MEC. [cited 2020 Apr 24]. Available from: <http://emec.mec.gov.br/>

10. Portal G1. Universidade de Fortaleza gradua 82 alunos da área de saúde em colação de grau antecipada em formato drive thru. [cited 2020 May 2]. Available from: https://g1.globo.com/ce/ceara/noticia/2020/04/14/ universidade-de-fortaleza-gradua-82-alunos-da-area-de-saude-em-colacao-de-grau-antecipada-em-formato-drive-thru.ghtml

11. Portal G1. Ceará tem 137 profissionais da saúde afastados por suspeita de coronavirus; 4 morreram [cited 2020 Apr 25]. Available from: https:// g1.globo.com/ce/ceara/noticia/2020/04/15/ceara-tem-137-profissionaisda-saude-afastados-por-suspeita-de-coronavirus-4-morreram.ghtml
12. Machado MH. Profissionais de saúde em tempos de Covid-19. [cited 2020 Apr 24]. Available from: http://www.cofen.gov.br/artigo-profissionais-desaude-em-tempos-de-covid-19_78151.html

13. Correia MITD, Ramos RF, Bahten LCV. Os cirurgiões e a pandemia do COVID-19. Rev Col Bras Cir. 2020;47:e20202536.

14. Costa MS, Dantas RT, Alves CGS, Ferreira ER, Silva AF. Espiritualidade e religiosidade: saberes de estudantes de medicina. Rev Bioética. 2019;27(2):350-8.

15. Lima DLF, Dias AA, Rabelo RS, Cruz ID, Costa SC, Nigri FMN, et al. COVID19 no Estado do Ceará, Brasil: comportamentos e crenças na chegada da pandemia. Ciên Saúde Coletiva. 2020;25(5):1575-86.

16. Gallasch $\mathrm{CH}$, Cunha ML, Pereira LAS, Silva-Júnior JS. Prevenção relacionada à exposição ocupacional do profissional de saúde no cenário de COVID-19. Rev Enferm UERJ. 2020;28:e49596.

17. Jackson Filho JM, Assunção AA, Algranti E, Garcia EG, Saito CA, Maeno M. A saúde do trabalhador e o enfrentamento da COVID-19. Rev Bras Saúde Ocup. 2020;45:e14.

18. Silva GMCD, Borges AR, Ezequiel ODS, Lucchetti ALG, Lucchetti G. Comparison of students' motivation at different phases of medical school. Rev Assoc Med Bras. 2018;64(10):902-8.

19. Wang J, Zhou M, Liu F. Reasons for healthcare workers becoming infected with novel coronavirus disease 2019 (COVID-19) in China. I Hosp Infect. 2020;105(1):100-1.

20. BRASIL. Ministério da Educação. Conselho Nacional de Educação. Resolução n ${ }^{0} 3$, de 20 de junho de 2014. Institui Diretrizes Curriculares Nacionais do Curso de Graduação em Medicina e dá outras providências. Diário Oficial da União. Brasília, 23 jun. 2014. Seção 1, p. 8-11.

21. Conselho Federal de Medicina (CFM). Nota de esclarecimento aos médicos e à população. Assunto: antecipação de formatura de estudantes de medicina. [cited 2020 Apr 23]. Available from: https://portal.cfm.org.br/ images/PDF/2020_nota_antecipacao_formatura.pdf

22. Associação Brasileira de Educação Médica (ABEM). Resultados preliminares do diagnóstico das escolas médicas na epidemia Covid-19. [cited 2020 Apr 20]. Available from: https://website.abem-educmed.org.br/ resultados-preliminares-diagnostico-escolas-medicas/

23. Oliveira SS, Postal EA, Afonso DH. As escolas médicas e os desafios da formação médica diante da epidemia brasileira da COVID-19: das (in) certezas acadêmicas ao compromisso social. APS em Revista. 2020;2(1):56-60.

24. Erku DA, Belachew SA, Abrha S, Sinnollareddy M, Thomas |, Steadman KI, et al. When fear and misinformation go viral: pharmacists' role in deterring medication misinformation during the 'infodemic' surrounding COVID-19. Res Social Adm Pharm. 2020;S1551-7411(20)30455-1.

25. Yazdany |, Kim AHJ. Use of hydroxychloroquine and chloroquine during the COVID-19 pandemic: what every clinician should know. Ann Intern Med. 2020;M20-1334. 